\title{
A Study on Influence of Milling Types and Cutting Conditions on Surface Roughness in Milling of Aluminum Alloy Al6061-T6
}

\author{
Nhu-Tung Nguyen \\ Faculty of Mechanical Engineering, Hanoi University of Industry, Vietnam \\ Received February 19, 2020; Revised May 6, 2020; Accepted May 20, 2020
}

Copyright $\odot 2020$ by authors, all rights reserved. Authors agree that this article remains permanently open access under the terms of the Creative Commons Attribution License 4.0 International License

\begin{abstract}
In this study, by using Taguchi method, with four controllable factors-three levels (milling type, axial depth of cut, feed rate, and spindle speed), the orthogonal array $\mathrm{L}_{27}$ was used to investigate the effects of milling type and cutting conditions on the surface roughness. By analysis of variance (ANOVA), the influences degree of milling type, axial cutting depth, feed rate, and spindle speed on the surface roughness were $9.26 \%, 12.85 \%$, $12.69 \%$, and $63.08 \%$, respectively. The interaction factors of these factors that have a quite small influence on the surface roughness. The surface roughness was modeled as a quadratic regression with the confidence level is more than $99.82 \%$. This model was successfully verified by comparison of experimental and predicted results. The optimization process of surface roughness was performed by both Taguchi method and the ANOVA analys is with the same results. The optimu $m$ value of surface roughness was $0.374 \mu \mathrm{m}$ that was obtained in the half up milling, at a cutting depth of $0.4 \mathrm{~mm}$, a feed rate of $480 \mathrm{~mm} / \mathrm{min}$, and a spindle speed of $5000 \mathrm{rpm}$.
\end{abstract}

Keywords Surface Roughness, Taguchi Method, ANOVA Analysis, Milling Processes, A16061-T6

\section{Introduction}

In the milling processes, the relationship between machining conditions and machining characteristics is very important to predict the quality of machining product, and predict the consumption of power, energy, as well. In order to investigate the influence of machining condition on machining characteristics (surface roughness, tool wear, cutting forces, etc.), many approaches were applied such as Taguchi method, response surface methodology (RSM), statistical methods of signal to noise ratio (SNR), Analysis of variance (ANOVA), and so on.

Taguchi method and ANOVA analysis have been widely used in industrial engineering analysis. Moreover, the Taguchi method employs a special design of orthogonal array through reducing the number of experiments to investigate the effect of the entire machining parameters. Recently, this method has been widely employed in several industrial fields, and research work. Lin et al. [1] and Lajis et al. [2] used Taguchi and ANOVA analysis to research the effect of main machining parameters such as mach ining pola rity, peak current, pulse duration, and so on, on the EDM machining characteristics such as material removal rate, surface roughness. Tsoukalas et al. [3] and Hsu et al. [4] used $\mathrm{L}_{27}$ orthogonal array of Taguchi method to determine the optimum conditions leading to minimum porosity in alu minum alloy die castings. Rao et al. applied the Taguchi method and ANOVA in optimization of process parameters for metal removal rate in electrochemical machining of $\mathrm{A} 1 / 5 \% \mathrm{SiC}$ composites [5]. Besides, the Taguchi method and ANOVA analysis were also applied to investigate other machining processes such as turning [6-9], drilling [10-12], and milling [13-15].

The surface roughness is important machining characteristics to evaluating the productivity of machining processes. In milling processes, by using Taguchi method and ANOVA analysis, the s and surface roughness could be investigated based on a number of factors such as depth of cut, feed rate, cutting speed, cutting time, workpiece hardness, etc. Several research works had been conducted in different conditions and had also been applied for different workpieces and tool materials [16-19]. The surface roughness was investigated and modeled depending on the cutting speed, depth of cut, feed rate, and cooling method in finishing milling of Hardox 400 steel with PVD TiAlN+TiN coated carbide inserts [20]. The optimization process of surface roughness was performed to determine the optimum values of machining parameters in 
finished face milling the hard steel SKD61 [21].

Many studies that were conducted to investigate the influence of cutting conditions on machined surface roughness. However, it seems that the influence of milling types and the interaction factors of milling types and cutting conditions on the surface roughness have not been mentioned. This study was carried out to determine the influence of milling types, cutting conditions, and the interaction factors of them on the surface roughness, and to improve the surface roughness of machined part by application of optimization methods.

\section{Materials and Methods}

\subsection{Experimental Setup}

\subsubsection{Workpiece and Cutter}

The workpiece material was Al6061-T6 with the hardness of $95 \mathrm{HB}$, Young's modulus of $68.9 \mathrm{GPa}$, Poisson's ratio of 0.33 , tensile strength $=310 \mathrm{MPa}$. And, the compositions of A16061-T6 are listed in Table 1.

Table 1. Chemical composites of Al6061-T6

\begin{tabular}{cccccccccc}
\hline Element & $\mathrm{Al}$ & $\mathrm{Cr}$ & $\mathrm{Cu}$ & $\mathrm{Fe}$ & $\mathrm{Mg}$ & $\mathrm{Mn}$ & $\mathrm{Si}$ & $\mathrm{Ti}$ & $\mathrm{Zn}$ \\
\hline $\begin{array}{c}\text { Composite } \\
(\%)\end{array}$ & & $\leq 8$ & $\leq$ & $\leq$ & $\leq$ & $\leq$ & $\leq$ & $\leq$ & $\leq$ \\
& & 0.3 & 0.4 & 0.7 & 1.2 & 0.15 & 0.8 & 0.15 & 0.25 \\
\hline
\end{tabular}

The cutter that were chosen was a carbide flat-end mill cutter with number of flutes of 4 flutes, a helix angle $\beta$ of $30^{\circ}$, a rake angle $\alpha_{\mathrm{r}}$ of $5^{0}$, and a diameter of $10 \mathrm{~mm}$.

\subsubsection{CNC Milling Machine and Surface Roughness Tester}

The CNC machine and surface roughness tester were used as described in Fig. 1. The experiments were performed at a three-axis vertical machining center (DECKEL MAHO - DMC70V hi-dyn). The surface roughness was measured by Mitutoyo SJ.400 portable surface roughness tester with the cutoff length of $0.8 \mathrm{~mm}$ and the evaluation length of $4 \mathrm{~mm}$.

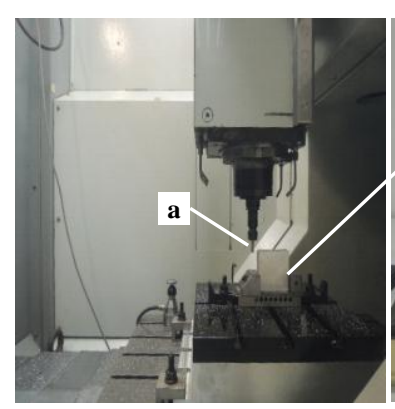

a. Cutter

b. Workpiece

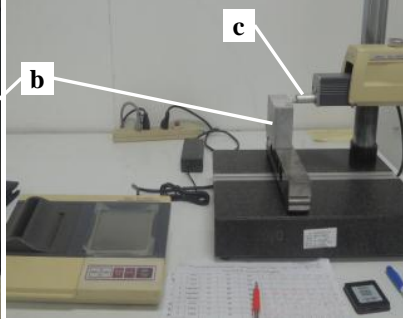

c. Surface roughness sensor
Figure 1. $\mathrm{CNC}$ machine and surface roughness tester

\subsubsection{Response Surface Methodology and Analys is of Variance (ANOVA)}

Response surface methodology is a collection of mathematical and statistical techniques that are useful for the modeling and analysis of problems in which a response of interest is influenced by several variables and the objective is to optimize this response. Almost all Response surface methodology problems use one or both of the first-order model and second-order model of polynomial that are given by Eq. (1) and Eq. (2), respectively [22].

$$
\begin{gathered}
y=\beta_{0}+\sum_{i=1}^{k} \beta_{i} x_{i}+\varepsilon \\
y=\beta_{0}+\sum_{i=1}^{k} \beta_{i} x_{i}+\sum_{i=1}^{k} \beta_{i i} x_{i}^{2}+\sum_{i}^{k} \sum_{j}^{k} \beta_{i j(i<j)} x_{i} x_{j}+\varepsilon
\end{gathered}
$$

where $\mathrm{k}$ represents number of independent variables; $\beta_{0}, \beta_{\mathrm{i}}, \beta_{\mathrm{ii}} \beta_{\mathrm{ij}}$ are the constants; $\varepsilon$ measures the experimental error (noise).

ANOVA analysis can be used to determine the effect of any given input parameter on any output parameter from a series of experimental results. Let $y_{i}$. represent the total of the observation under the $i^{\text {th }}$ treatment that is given by Eq. (3) and $\bar{y}_{i}$. represent the average of the observations under the $\mathrm{i}^{\text {th }}$ treatment that is given by Eq. (4). Similarly, let $\mathrm{y}$. represent the grand total of all the observations that is given by Eq. (5) and $\bar{y}_{\text {.. }}$ represent the grand average of all the observations that is given by Eq. (6), [22].

$$
\begin{gathered}
y_{i .}=\sum_{j=1}^{n} y_{i j} \quad i=1,2, \ldots, m \\
\bar{y}_{i .}=\frac{y_{i .}}{n} \quad i=1,2, \ldots, m \\
y_{. .}=\sum_{i=1}^{m} \sum_{j=1}^{n} y_{i j} \\
\bar{y}_{. .}=\frac{y_{. .}}{N}
\end{gathered}
$$

Where $\mathrm{N}=\left(\mathrm{m}^{*} \mathrm{n}\right)$ is the total number of observations.

ANOVA partitions total variation into its appropriate components. Total sum of squares term can be calculated by Eq. (7), [22].

$$
\mathrm{SS}_{\mathrm{T}}=\sum_{\mathrm{i}=1}^{\mathrm{m}} \sum_{\mathrm{j}=1}^{\mathrm{n}}\left(\mathrm{y}_{\mathrm{ij}}-\overline{\mathrm{y}}_{. .}\right)^{2}
$$

The Eq. (7) can be rewritten by Eq. (8).

$$
\mathrm{SS}_{\mathrm{T}}=\mathrm{SS}_{\text {Treatments }}+\mathrm{SS}_{\mathrm{E}}
$$

Where $\mathrm{SS}_{\text {Treatments }}$ is a sum of squares of differences between the treatment average and the grand average, and $\mathrm{SS}_{\mathrm{E}}$ is a sum of squares of the differences of observations within treatments from the treatment average. $\mathrm{SS}_{\text {Treatments }}$ and $\mathrm{SS}_{\mathrm{E}}$ can be calculated by Eq. (9) and Eq. (10).

$$
\begin{gathered}
\mathrm{SS}_{\text {Treatments }}=\mathrm{n} \sum_{\mathrm{j}=1}^{\mathrm{n}}\left(\mathrm{y}_{\mathrm{i} .}-\overline{\mathrm{y}}_{. .}\right)^{2} \\
\mathrm{SS}_{\mathrm{E}}=\sum_{\mathrm{i}=1}^{\mathrm{m}} \sum_{\mathrm{j}=1}^{\mathrm{n}}\left(\mathrm{y}_{\mathrm{ij}}-\overline{\mathrm{y}}_{\mathrm{y}}\right)^{2}
\end{gathered}
$$




\subsection{Taguchi Method and Experiment Design}

Taguchi method is a statistical method used to improve the product quality. It is commonly used in improving industrial product quality due to the proven success. It is an experimental design and also a beneficial technique for high quality system design. In engineering analysis, the Taguchi method is a powerful method and it has been widely used in the world. This method dramatically reduces the number of tests by using orthogonal arrays and minimizes the effects of factors that cannot be controlled [23].

The parameter design study involves control and noise factors. The measurement of interactions between these factors with regard to robustness is signal-to-noise $(\mathrm{S} / \mathrm{N})$ ratio. Normally, there are three kinds of quality characteristics in the analysis of the $\mathrm{S} / \mathrm{N}$ ratio, namely the bigger-the-better, the smaller-the-better, and the nominal-the-better [24-25] that can be calculated by Eq. (11) to Eq. (13). For each level of the process parameters, the $\mathrm{S} / \mathrm{N}$ ratio is calculated based on the $\mathrm{S} / \mathrm{N}$ analysis.

The bigger-the-better:

$$
\frac{\mathrm{S}}{\mathrm{N}_{\mathrm{s}}}=-10 \log \left[\frac{1}{\mathrm{n}} \sum_{\mathrm{i}=1}^{\mathrm{n}} \frac{1}{\mathrm{y}_{\mathrm{i}}^{2}}\right]
$$

The smaller-the-better:

$$
\frac{\mathrm{s}}{\mathrm{N}_{\mathrm{s}}}=-10 \log \left[\frac{1}{\mathrm{n}} \sum_{\mathrm{i}=1}^{\mathrm{n}} \mathrm{y}_{\mathrm{i}}^{2}\right]
$$

The nominal-the-better:

$$
\frac{s}{N_{s}}=-10 \log \left[\frac{\bar{y}}{s_{y}^{2}}\right]
$$

Where, $\bar{y}$ is the average of observed data, $S_{y}^{2}$ is the variance of $y$, and $n$ is the number of observations.

The cutting types (A), axial depth of cut (B), feed rate (C), and spindle speed (D) were selected as control factors and their levels were expressed in the Table 2. In the experimental layout plan, with four factors and three levels, the most suitable orthogonal array $\left(\mathrm{L}_{27}-3^{4}\right)$ was chosen to analyze the effects of machining parameters on the surface roughness [24-25]. The experimental plan was performed with 27 experiments and detailed as in Table 3.

Table 2. Milling parameters and their levels

\begin{tabular}{|c|c|c|c|c|c|}
\hline \multirow{2}{*}{$\begin{array}{l}\text { Run } \\
\text { No. }\end{array}$} & \multicolumn{4}{|c|}{ Coded factors } & \multirow{2}{*}{$\begin{array}{c}\mathbf{R}_{\mathrm{a}} \\
{[\boldsymbol{\mu \mathrm { m }}]}\end{array}$} \\
\hline & $\mathbf{A}$ & B & $\mathbf{C}$ & D & \\
\hline 1 & -1 & -1 & -1 & -1 & 1.048 \\
\hline 2 & -1 & -1 & 0 & 0 & 1.012 \\
\hline 3 & -1 & -1 & 1 & 1 & 0.446 \\
\hline 4 & -1 & 0 & -1 & 0 & 0.904 \\
\hline 5 & -1 & 0 & 0 & 1 & 0.802 \\
\hline 6 & -1 & 0 & 1 & -1 & 1.574 \\
\hline 7 & -1 & 1 & -1 & 1 & 0.492 \\
\hline 8 & -1 & 1 & 0 & -1 & 1.890 \\
\hline 9 & -1 & 1 & 1 & 0 & 1.600 \\
\hline 10 & 0 & -1 & -1 & -1 & 1.244 \\
\hline 11 & 0 & -1 & 0 & 0 & 1.146 \\
\hline 12 & 0 & -1 & 1 & 1 & 0.476 \\
\hline 13 & 0 & 0 & -1 & 0 & 1.018 \\
\hline 14 & 0 & 0 & 0 & 1 & 0.994 \\
\hline 15 & 0 & 0 & 1 & -1 & 1.718 \\
\hline 16 & 0 & 1 & -1 & 1 & 0.540 \\
\hline 17 & 0 & 1 & 0 & -1 & 2.016 \\
\hline 18 & 0 & 1 & 1 & 0 & 1.690 \\
\hline 19 & 1 & -1 & -1 & -1 & 1.600 \\
\hline 20 & 1 & -1 & 0 & 0 & 1.460 \\
\hline 21 & 1 & -1 & 1 & 1 & 0.662 \\
\hline 22 & 1 & 0 & -1 & 0 & 1.300 \\
\hline 23 & 1 & 0 & 0 & 1 & 1.114 \\
\hline 24 & 1 & 0 & 1 & -1 & 2.060 \\
\hline 25 & 1 & 1 & -1 & 1 & 0.752 \\
\hline 26 & 1 & 1 & 0 & -1 & 2.330 \\
\hline 27 & 1 & 1 & 1 & 0 & 1.972 \\
\hline
\end{tabular}

\begin{tabular}{|c|c|c|c|c|c|}
\hline \multirow{2}{*}{ No. } & \multirow{2}{*}{$\begin{array}{c}\text { Actual } \\
\text { factors }\end{array}$} & \multirow{2}{*}{$\begin{array}{c}\text { Coded } \\
\text { factor }\end{array}$} & Level 1 & Level 2 & Le vel 3 \\
\cline { 4 - 6 } & & $\mathbf{- 1}$ & $\mathbf{0}$ & $\mathbf{1}$ \\
\hline 1 & Milling type & A & Half up & $\begin{array}{c}\text { Half } \\
\text { down }\end{array}$ & Slotting \\
\hline 2 & $\begin{array}{c}\text { Axial cutting } \\
\text { depth a (mm) }\end{array}$ & B & 0.4 & 0.8 & 1.2 \\
\hline 3 & $\begin{array}{c}\text { Feed rate F } \\
\text { (mm/min) }\end{array}$ & C & 480 & 720 & 960 \\
\hline 4 & $\begin{array}{c}\text { Spindle speed } \\
\text { (rpm) }\end{array}$ & D & 1000 & 3000 & 5000 \\
\hline
\end{tabular}

Table 3. The experimental design with orthogonal array of Taguchi $\mathrm{L}_{27}\left(3^{4}\right)$

\section{Results and Discussions}

\subsection{Analysis of Variance}

The surface roughness in milling process were measured and stored as in Table 2. The Analysis of Variance (ANOVA) was used to analyze the effects of cutting type, axial depth of cut, feed rate, and spindle speed on the surface roughness. Using Intercooled Stata $8.2^{\mathrm{TM}}$ software, these ANOVA results were shown in Table 4. The coefficient of determination $\left(\mathrm{R}^{2}\right)$ is defined as the ratio of the explained variation to the total variation and is a measure of the fit degree. In this work, this analysis was performed with $95 \%$ confidence level and $5 \%$ significance level which indicates that the obtained models are considered to be statistically significant. 
In Table 4, the contributions of each factor on the surface roughness were listed in the last colu $\mathrm{mn}$. It is clear from the results of ANOVA that the most important factor affecting on the surface roughness was spindle speed (factor D, $63.08 \%)$. The other factors affect differently on the surface roughness. The axial cutting depth and feed rate had the same influence on the surface roughness $(12.85 \%$ for axial cutting depth and $12.69 \%$ for feed rate). The fourth factors that influenced on the surface roughness were milling type (factor A, $9.26 \%$ ). The interaction factors of these factors that has quite small influence on the surface roughness.

\subsection{Regression and Verification of Surface Roughness Model}

In this work, the dependent variable is the surface roughness $(\mathrm{Ra})$, whereas the independent variables are milling type (A), axial depth of cut (B), feed rate (C), and spindle speed (D). By using Intercooled Stata $8.2^{\mathrm{TM}}$ software, the surface roughness was modelled by quadratic function as given by Eq. (20) and Eq. (21). The $\mathrm{R}^{2}$ values of the equations obtained by quadratic regression model for surface roughness were found to be $99.82 \%$.

$$
\left\{\begin{array}{c}
\mathrm{Ra}=1.422+0.193 \mathrm{~A}+0.233 \mathrm{~B}+0.167 \mathrm{C} \\
-0.438 \mathrm{D}-0.012 \mathrm{BA}+0.011 \mathrm{CA} \\
+0.146 \mathrm{CB}-0.058 \mathrm{DA}-0.032 \mathrm{DB} \\
+0.074 \mathrm{~A}^{2}-0.033 \mathrm{~B}^{2}-0.230 \mathrm{C}^{2}-0.063 \mathrm{D}^{2} \\
\mathrm{R}^{2}=99.82 \%, \mathrm{R}_{\mathrm{Ajd}}^{2}=99.64 \%
\end{array}\right.
$$

Where the relationship between actual factors and coded factors was expressed by Eq. (21).

$$
\left\{\begin{aligned}
A= & \left\{\begin{array}{l}
-1 \text { if up milling } \\
0 \text { if down milling } \\
1 \text { if slotting }
\end{array}\right. \\
B & =\frac{a-0.8}{0.4} \\
C & =\frac{F-720}{240} \\
D & =\frac{S-3000}{2000}
\end{aligned}\right.
$$

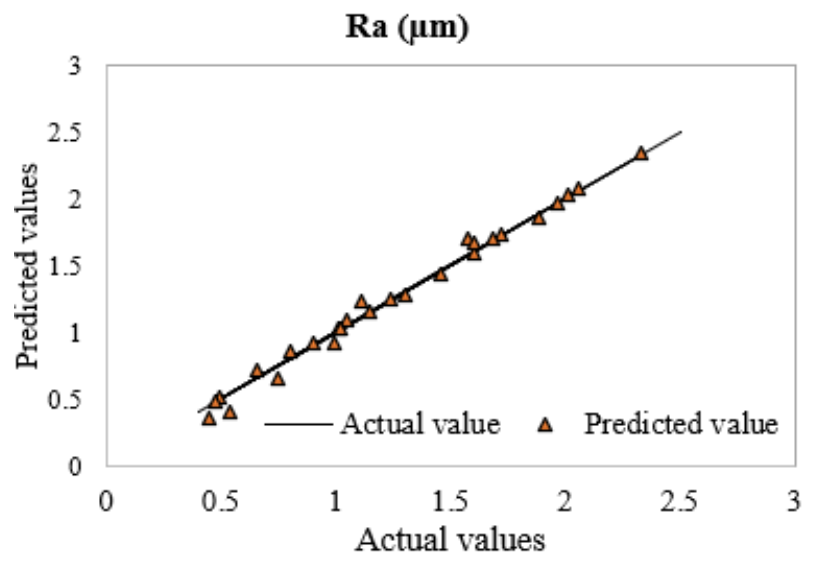

Figure 2. Experimental and predicted values of surface roughness
The verification results of surface roughness model were described in Fig. 2. As seen from this figure, the predicted results were very close to the experimental results. There is a very good relation between predicted values and actual values.

These results showed that the quadratic regression model was shown to be successfully investigated of surface roughness in milling process of aluminum alloy A16061-T6.

\subsection{Parametric Influence on Surface Roughness}

The parametric influence of milling types and cutting conditions on the surface roughness was described in Fig 3 . It is very clear that in up milling process, the surface roughness value was smallest, down milling gave the larger surface roughness than up milling, and slotting gave the largest surface roughness. Besides, the surface roughness increased with increasing of feed rate. This trend can be explained that when feed rate increased, the undeform chip thickness also increased, and undeform chip thickness is directly proportional to cutting forces. And then, when the cutting forces increased, the stability and damping characteristics of machine-tool system will be affected, that makes more vibrations and ultimately affects the surface roughness.

The surface roughness values exhibited increasing tendency with increasing of axial depth of cut from 0.4 $\mathrm{mm}$ to $1.2 \mathrm{~mm}$. Otherwise, the surface roughness decreases with increasing of spindle speed from $1000 \mathrm{rpm}$ to $5000 \mathrm{rpm}$. So, in order to improve the surface roughness in milling process of aluminum alloy A16061-T6, the tendency of machining conditions was proposed that the milling type is up milling, the feed rate decreases, the axial depth of cut decreases, and the spindle speed increases. In comparison of this study with other studies [7, 21], it seems that the tendency of surface roughness that was investigated in this study is quite similar to the one in previous studies.

\subsection{Estimation of Optimum Surface Roughness by ANOVA Analysis and Taguchi Method}

\subsubsection{The Optimization Parameter of Milling Proces s by ANOVA Analysis}

The lowest value of surface roughness is very important for quality improvement of the machining product and lowering production costs. The quadratic regression model of surface roughness as presented by Eq. (20) was used to determine the optimized values of surface roughness and machining parameters.

The optimized results of machining parameters were obtained as below:

$$
\begin{gathered}
\mathrm{x}=\left[\begin{array}{lll}
\approx-1, & -1, \quad-1, & 1
\end{array}\right] \Rightarrow \mathrm{A}=-1 ; \mathrm{B}=-1 ; \mathrm{C}=-1 ; \mathrm{D}=1 . \\
\text { fval }=0.374
\end{gathered}
$$


So by ANOVA analysis, the optimal parameters of machining process were determined as below:

Milling type: Half up milling

Axial depth of cut: $a=0.4 \mathrm{~mm}$

Feed rate: $\mathrm{F}=480 \mathrm{~mm} / \mathrm{min}$

Spindle speed: $\mathrm{S}=5000 \mathrm{rpm}$

And the optimization value: $\mathrm{Ra}=0.374 \mu \mathrm{m}$

\subsubsection{The Optimization Parameter of Milling Process by} Taguchi Method

By using Taguchi method, the optimal values of control factor were determined by analysis of the signal-to-noise ratio. As in ANOVA analysis, the lowest value of surface roughness is very important to improve the machining product, so the smaller-the-better equation was used for calculation of the $\mathrm{S} / \mathrm{N}$ ratio that was determined by $\mathrm{Eq}$. (12). The values of the $\mathrm{S} / \mathrm{N}$ response for observations of surface roughness were listed in Table 5.

Table 4. Results of ANOVA for surface roughness

\begin{tabular}{|c|c|c|c|c|c|c|c|}
\hline \multicolumn{2}{|c|}{ Number of obs: 27} & & & \multicolumn{3}{c|}{ R-squared: 0.9988} \\
\hline \multicolumn{2}{|c|}{ Root MSE: 0.0307} & & \multicolumn{3}{c|}{ Adj R-squared: 0.9968} \\
\hline \multicolumn{2}{|c|}{ Variance source } & $\begin{array}{c}\text { Sum of } \\
\text { squares }\end{array}$ & $\begin{array}{c}\text { Degree of } \\
\text { freedom }\end{array}$ & $\begin{array}{c}\text { Mean } \\
\text { square }\end{array}$ & F-value & Prob > F & $\begin{array}{c}\text { Percent } \\
\text { contribution (\%) }\end{array}$ \\
\hline \multicolumn{2}{|c|}{ Model } & $\mathbf{7 . 6 2 3 9}$ & $\mathbf{1 6}$ & $\mathbf{0 . 4 7 6 5}$ & $\mathbf{5 0 5 . 5 4}$ & $\mathbf{0 . 0 0 0 0}$ & \\
\hline Milling type & A & 0.7065 & 2 & 0.3533 & 374.8 & 0.0000 & 9.26 \\
\hline a $(\mathrm{mm})$ & B & 0.9809 & 2 & 0.4905 & 520.34 & 0.0000 & 12.85 \\
\hline F $(\mathrm{mm} / \mathrm{min})$ & C & 0.9687 & 2 & 0.4844 & 513.9 & 0.0000 & 12.69 \\
\hline S (rpm) & D & 4.8151 & 2 & 2.4076 & 2554.28 & 0.0000 & 63.08 \\
\hline & A*B & 0.0036 & 2 & 0.0018 & 1.92 & 0.1969 & 0.05 \\
\hline & A*C & 0.0033 & 2 & 0.0017 & 1.77 & 0.2196 & 0.04 \\
\hline & A*D & 0.0404 & 2 & 0.0202 & 21.45 & 0.0002 & 0.53 \\
\hline & B*C & 0.1007 & 2 & 0.0504 & 106.85 & 0.0000 & 1.32 \\
\hline & B*D & 0.0046 & 1 & 0.0046 & 4.89 & 0.0515 & 0.06 \\
\hline & Error & 0.0094 & 10 & 0.0009 & & & 0.12 \\
\hline
\end{tabular}



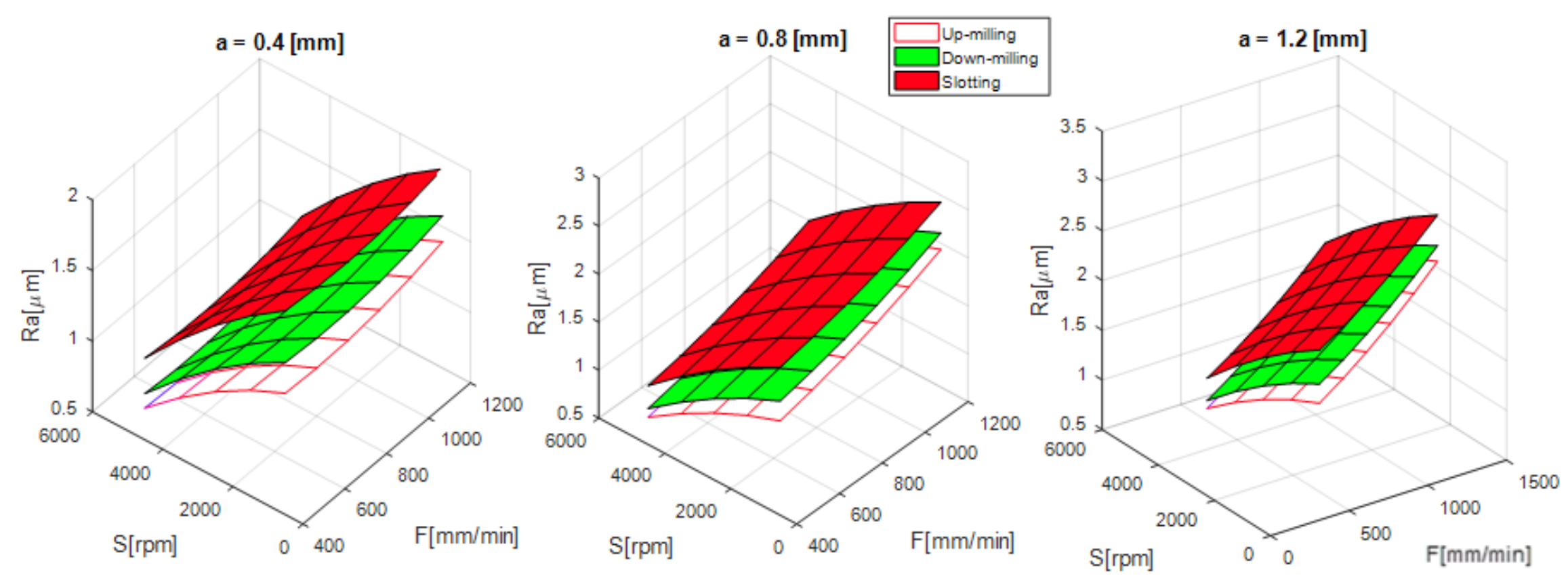

Figure 3. Effect of cutting conditions on surface roughness 


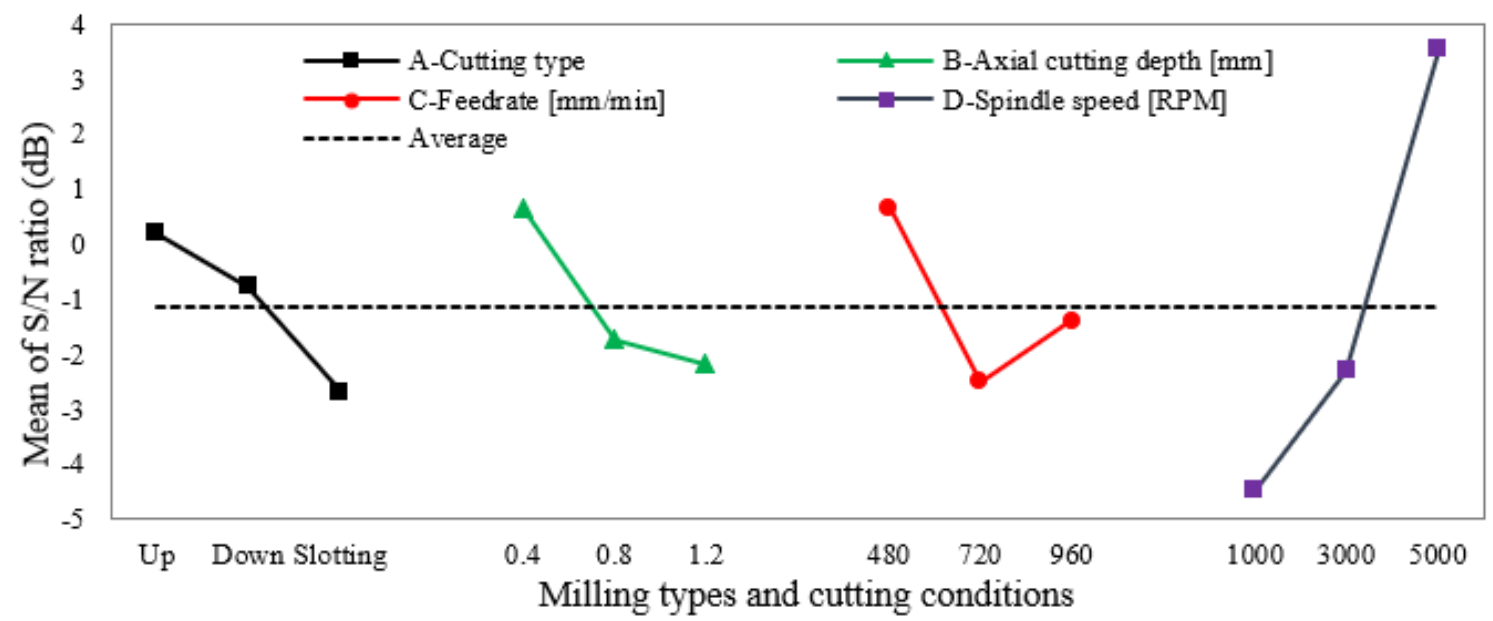

Figure 4. Main effects of each factor on surface roughness

The effect of milling types and cutting conditions on the surface roughness were evaluated and shown in Fig 4. The results from this figure showed that up milling gave the best surface, down milling gave the second good surface, and finally, that is slotting. With other machining parameters, the surface roughness values exhibited decreasing tendency with decreasing of axial depth of cut and feed rate.

Table 5. The $\mathrm{S} / \mathrm{N}$ response for surface roughness

\begin{tabular}{|c|c|c|c|c|}
\hline \multirow{2}{*}{ Levels } & \multicolumn{4}{|c|}{ Control factors } \\
\cline { 2 - 5 } & $\mathrm{A}$ & $\mathrm{B}$ & $\mathrm{C}$ & $\mathrm{D}$ \\
\hline Level 1 & $\mathbf{0 . 2 0 6 3}$ & $\mathbf{0 . 6 6 7 9}$ & $\mathbf{0 . 6 6 7 4}$ & -4.4757 \\
\hline Level 2 & -0.7532 & -1.7181 & -2.5025 & -2.2978 \\
\hline Level 3 & -2.6749 & -2.1716 & -1.3867 & $\mathbf{3 . 5 5 1 7}$ \\
\hline Delta & 2.8812 & 2.8395 & 3.1699 & 8.0274 \\
\hline
\end{tabular}

The tendency of surface roughness was reversed with the spindle speed that it decreased with increasing of spindle speed. So, in order to improve the surface roughness in the milling process, the tendency of milling type and machining conditions were proposed that were up milling, decreasing the axial depth of cut, the feed rate, and increasing the spindle speed.

By Taguchi techniques, the best level of each control factor was determined according to the highest $\mathrm{S} / \mathrm{N}$ ratio at the level of that control factor. By these techniques, from the values of Table 5 and Fig. 5, the level and S/N ratios for input factors that gave the best $\mathrm{Ra}$ value were specified as factor A (level - $1, \mathrm{~S} / \mathrm{N}=0.2063 \mathrm{~dB}$ ), factor B (level $-1, \mathrm{~S} / \mathrm{N}$ $=0.6679 \mathrm{~dB})$, factor $\mathrm{C}$ (level $-1, \mathrm{~S} / \mathrm{N}=0.6674 \mathrm{~dB})$, and factor D (level 1, S/N $3.5517 \mathrm{~dB}$ ). By using Taguchi method, the optimum value of surface roughness was obtained in the up milling $(\mathrm{A}=-1)$, at a depth of cut of 0.4 $\mathrm{mm}(\mathrm{B}=-1)$, a feed rate of $480 \mathrm{~mm} / \mathrm{min}(\mathrm{C}=-1)$, and a spindle speed of $5000 \mathrm{rpm}(\mathrm{D}=1)$. So, it can be concluded that the optimized results between ANOVA analysis and
Taguchi method are the same.

\section{Conclusions}

Depending on the analysis of experimental results, the conclusions of this study can be drawn as follows.

The most important factor affecting on the surface roughness was spindle speed. The axial cutting depth and feed rate had the same influence on the surface roughness. Milling type and interaction factors has quite small influence on the surface roughness.

The most suitable regression of surface roughness was a quadratic regression with the confidence level is $99.82 \%$, and this model was successfully verified by comparison of experimental and predicted results.

In this milling process, up milling gave the best surface, down milling gave the second good surface, and finally, that is slotting. With other machining parameter, the surface roughness values exhibited decreasing tendency with decreasing of axial depth of cut and feed rate. The tendency of surface roughness was reversed with the spindle speed that it decreased with increasing of spindle speed.

The optimized results from Taguchi method and the ANOVA analysis are the same. The optimum value of surface roughness is $0.3735 \mu \mathrm{m}$ that was obtained in the half-up milling, at a depth of cut of $0.4 \mathrm{~mm}$, a feed rate of $480 \mathrm{~mm} / \mathrm{min}$, and a spindle speed of $5000 \mathrm{rpm}$.

\section{REFERENCES}

[1] Y.C. Lin, Y.F. Chen, D.A. Wang, H.S. Lee, "Optimization of machining parameters in magnetic force assisted EDM based on Taguchi method," Journal of Materials Processing Technology, Vol. 209, No. 7, p.3374-3383, 2009.

[2] M.A. Lajis, H.C.D. M. Radzi, A.K.M. Nurul Amin, "The 
implementation of Taguchi Method of EDM Process of Tungsten Carbide," European Journal of Scientific Research, ISSN 1450-216X, Vol.26 No.4,pp.609-617, 2009.

[3] V.D. Tsoukalas, "Optimization of porosity formation in AlSi9Cu3 pressure die casting using genetic algorithm analysis," Material and Design29: 2027-2033, 2008.

[4] Q.C. Hsu, A.T. Do, "Minimum Porosity Formation in Pressure Die Casting by Taguchi Method," Mathematical Problems in Engineering, Vol 2013.

[5] S.R. Rao, G. Padmanabhan, "Application of Taguchi methods and ANOVA in optimization of process parameters for metal removal rate in electrochemical machining of $\mathrm{Al} / 5 \% \mathrm{SiC}$ composites," International Journal of En gin eering Research and Applications, Vol. 2, Issue 3, pp. 192-197, 2012.

[6] C. Fetecau, F. Stan, "Study of surface roughness in the turning of polytetrafluoroethylene composites with a poly crystalline diamond tool," Measurement 45: 1367-1379, 2012.

[7] Kara, F. and Öztürk, B. (2019), "Comparison and optimization of PVD and CVD method on surface roughness and flank wear in hard-machining of DIN 1.2738 mold steel", Sensor Review, Vol. 39 No. 1, pp. 24-33. https://doi.org/10.1108/SR-12-2017-0266

[8] H. Aouici, M.Y. Yallese, K. Chaoui, T. Mabrouki, J.F. Rigal, "Analysis of surface roughness and components in hard turning with CBN tool: Prediction model and cutting conditions optimization,"Measurement 45: 344-353, 2012.

[9] F. Kolahan, M. Manoochehri, A. Hosseini, "Application of Taguchi Method and ANOVA Analysis for Simultaneous Optimization of Machining Parameters and Tool Geometry in Turning," World Academy of Science Engineering and Technology 74, 2011.

[10] A.N. Siddiqueea, Z.A. Khan, P. Goel, M. Kumar, G Agarwal, N.Z. Khan, "Optimization of Deep Drilling Process Parameters of AISI 321 Steel using Taguchi Method,"Procedia Materials Science 6: 1217 - 1225, 2014.

[11] J. Prasanna, L. Karunamoorthy, V.M. Raman, S. Prashanth, D.R. Chordia, "Optimization of process parameters of small hole dry drilling in Ti-6Al-4V using Taguchi and grey relational analysis," Measurement 48:346-354, 2014.

[12] A. Çiçek, T. Kıvak, G. Samtaş, “Application of Taguchi Method for Surface Roughness and Roundness Error in Drilling of AISI 316 Stainless Steel," Journal of Mechanical Engineering 58: 165-174, 2012.

[13] J.A. Ghani, I.A. Choudhury, H.H. Hassan, "Application of Taguchi method in the optimization of end milling parameters," J. Mater. Processing Technol. 145: 84-92, 2004.

[14] Y. Turgut, H. Çinici, I. Sahin, and T. Findik, "Study of and surface roughness in milling of $\mathrm{Al} / \mathrm{Sic}$ metal matrix composites," Scientific Research and Essays Vol. 6(10), pp. 2056-2062, 2011.

[15] T.R. Lin, "Experimental design and performance analy sis of TiN coated carbide tool in face milling stainless steel," J Mater Process Technol 127:1-7, 2002.

[16] T. Kivak, “Optimization of surface roughness and flank wear using the Taguchi method in milling of Hadfield steel with PVD and CVD coated inserts," Measurement 50: 19-28, 2014.

[17] B. Ozcelik, M. Bayramoglu, "The statistical modeling of surface roughness in high-speed flat end milling," International Journal of Machine Tools \& Manufacture 46: 1395-1402, 2006.

[18] M.S. Karakas, A. Acır, M. Übeyli, B. Ögel, "Effect of cutting speed on tool performance in milling of B4Cp reinforced aluminum metal matrix composites," Journal of Materials Processing Technology 178: 241-246, 2006.

[19] K. Jay akumar, J. Mathew, M.A. Joseph, “An investigation of and tool-work interface temperature in milling of $\mathrm{Al}-\mathrm{SiCp}$ metal matrix composite," Journal of Engineering Manufacture 227: 362, 2013.

[20] Fuat Kara, Optimization of Cutting Parameters in Finishing Milling of Hardox 400 Steel, International Journal of Analytical, Experimental and Finite Element Analysis (IJAEFEA), Issue. 3, Vol. 5, Oct 2018 e-ISSN: 2394-5141, p-ISSN: 2394-5133, pp 44-49.

[21] Hoang, Tien Dung, Nhu-Tung Nguyen, Đuc Quy Tran, and Van Thien Nguyen. "Cutting Forces and Surface Roughness in Face-Milling of SKD61 Hard Steel." Strojniski Vestnik/Journal of Mechanical Engineering 65, no. 6, 2019.

[22] D.C. Montgomery, "Design and analy sis of experiments,". 5th ed. New York: Wiley,2001.

[23] A.R. Motorcu, "The Optimization of Machining Parameters Using the Taguchi Method for Surface Roughness of AISI 8660 Hardened Alloy Steel," Strojniški vestnik - Journal of Mechanical Engineering, vol. 56, no. 6, p. 391-401, 2010.

[24] R.K. Roy, "Design of Experiments Using the Taguchi Approach: 16 Steps to Product and Process Improvement," John Wiley \& Sons, 2001.

[25] G. Taguchi, "Taguchi on Robust Technology Development," ASME, New York, 1993. 